\title{
Determination of phenolic components of Vitex agnus-castus L. (Verbenaceae) from Muğla-Ula region in Turkey
}

\author{
Muğla-Ula yöresinde Vitex agnus-castus L. (Verbenaceae) fenolik bileşenlerinin belirlenmesi
}

\section{Sevgin ÖZDERIN ${ }^{10}$ (iD}

${ }^{1}$ Mugla Sıtkı Kocman University, Köycegiz Vocational School, 48000 Mugla, Turkey.

\section{MAKALE BILGISI / ARTICLE INFO}

\section{Makale tarihçesi / Article history:}

DOI: $10.37908 /$ mkutbd.937814

Geliş tarihi /Received:21.05.2021

Kabul tarihi/Accepted:07.09.2021

\section{Keywords:}

Verbenaceae, Vitex agnus castus, phenolic components, Muğla-Ula, Turkey.

\footnotetext{
Corresponding author: Sevgin ÖZDERIN

$\triangle:$ sevginozderin@mu.edu.tr
}

\author{
ÖZET / A B STR A C T
}

Atıf / Citation: Özderin S (2021) Determination of phenolic components of Vitex agnus-castus L. (Verbenaceae) from MuğlaUla region in Turkey. MKU. Tar. Bil. Derg. 26(3) : 692-699. DOI: 10.37908/mkutbd.937814

\section{INTRODUCTION}

The use of natural resources in therapy originated with the history of humanity. The earliest archives about use of plants in the treatment of diseases date back to written sources from Chinese, Indian and North African civilizations (Harvey, 2008; John, 2009; Phillipson, 2001; Rishton, 2008). Many medicinal plants discovered by trial and error in our country, known as medicinal plants, are applied in the treatment of diseases, just as they are in other parts of the world. The Anatolian people have benefitted from the use of medicine and food derived 
from wild plants concurrently with human settlement. In developing countries, herbal medicines are an integral part of the culture and pract ices of rural communities (Yiğit and Benli 2005, Çenet and Toroğlu, 2006; Njume et al., 2009). Plant applied for the production of new and highly effective drug formulations has also been one of the pharmacology research areas due to the rich chemical structures of plants (Kulkarni and Vijiyanand, 2010; Jose et al., 2018; Mohammed et al., 2019). Considering today, despite the fact that synthetic products account for a large portion of the pharmaceutical industry, natural drug active ingredients and drugs manufactured from natural compounds account for roughly half of all drugs used today(Harvey, 2008; John, 2009; Phillipson, 2001; Rishton, 2008; Kültür, 2007).

Plants which are applied directly or indirectly as herbal medicine raw materials are called "Medicinal Plants". Most of the medicinal plants consist of aromatic plants. Nowadays, the term "medicinal" and "aromatic" plants are generally accepted together (Baydar, 2005). Many medicinal and aromatic plants are applied in a variety of fields because of the active chemical compounds present in their seeds, fruits, leaves, and roots due to their different modes of action (Maksimović et. al., 2005). Bioactive compounds that develop from a result of secondary metabolic activities of plants, cannot be consumed as food but have beneficial effects for human health are called 'phytochemicals' (Visioli et al., 2000; Sevindik, 2018). In recent years, there has been an increasing interest in phenolic compounds due to the antioxidant properties of phenolics. Antioxidants extracted from natural sources are preferred for use in food industry, pharmaceutical industry, fungicides and pesticides industry (Kähkönen et al., 1999; Willför et al., 2003). Most plants contain phenolic compounds, which are low-molecular secondary compounds. Phenolic compounds can be classified as soluble compounds such as phenolic acids, flavonoids, phenylpropanoids and quinones, and insoluble compounds such as condensed tannins, lignins, cell wall binding hydrocinnamic acid (Balasundram et al., 2006; Meral et al., 2012.). Phenolic compounds have been shown to be a preventive factor in heart disease and cancer treatment. Researches on plant phenolic components that are industrially significant are frequently carried out, and studies on alternative sources are increasing day by day (Kähkönen et al., 1999; Willför et al., 2003).

Verbenaceae family plants are defined as the family of plants generally used in traditional medicine in various countries. Verbenaceae is a family consisting of approximately 3000 species, rarely herbaceous plants in tropical and subtropical regions, and species in the form of shrubs or bushes (Gülsoy, 2011; Rahmatullah et al., 2011). It is a species that generally spreads in the Mediterranean Region, Central Asia and Southern Europe (Ono et al., 2011). V. agnus-castus L. (Hayit) is known by the people with names such as 'Hayıt', 'Ayıd', 'Ayıt', 'Beşparmak Herb', 'Priest pepper' and 'Chaste tree' and it has different usage styles. $V$. agnus-castus is a deciduous, 3-6 m tall, round-crowned, upright and lowbranching shrub or bushes with a thin medium texture (Brickell and Zuk, 1996; Cheifetz et al., 1999). The inflorescences are delicate, dense, fragrant, lilac-pink or rarely white colored spike or compound spike (Kayacık, 1966; Cheifetz et al., 1999). Local flowers and fruits have been applied in various cultures since ancient times (Bohnert and Hahn, 1990). It is known that the $V$. agnuscastus species has been used in the medical field for more than 2000 years (Asdadi et al., 2015). It was first mentioned in the inscriptions of Hippocrates in the 4th century BC (Odenthal, 1998). In addition, the moderate cytotoxic and pro-apoptotic effects of $V$. agnus-castus extracts on human cancer cells have also been investigated (Sezik et al., 2013). In another study, it was suggested that $V$. agnus-castus can be applied as a valuable tool in the treatment of bone resorption, benign growth of the prostate and prostate cancer in men (Ignjatović et al., 2012).

Vitex agnus-castus seeds or extracts obtained from fruit are applied among the public for therapeutic purposes, to eliminate fibroid cysts, infertility, menopause and menstrual period irregularities and troubles in women, to increase milk yield in breastfeeding mothers, acne problems, and impotence and stress in men (Odenthal, 1998; Baytop, 1999; Arokiyaraj et al., 2009; Bachrach, 2012; Ohyama et al., 2003; Stojković et al., 2011). In many studies conducted with $V$. agnus-castus samples, its chemical components were investigated and its hormonal effect was researched. For this reason, it has been stated that $V$. agnus-castus is a herbal alternative in the treatment of hormonal disorders and in relieving their symptoms (Wuttke et al., 2003). It has been stated that the estrogenic, dopaminergic and opioidergic properties of $\mathrm{V}$. agnus castus are partially related to their phenolic component content of it, although their efficacy in the treatment of gynecology has not been fully investigated (Rani and Sharma, 2013; Webster et al., 2006)

It has been found out that $V$. agnus-castus leaf, flower and fruit are rich in phenolic acids and their derivatives, flavonoids, tannins, iridoids, diterpenoids and essential oil composition (Sağlam et al., 2007; Hajdú et al., 2007; 
Proestos et al., 2006; Cabral et al., 2008; Stojković et al., 2011; Latovi et al., 2012; Fakir et al., 2014).

In another study, it was determined that the leaves and fruits of $V$. agnus castus contain a significant level of vitexin compound.Vitexin has many biological properties such as, antioxidant, antimicrobial, anti-inflammatory, hepatoprotective, spasmolytic, antiviral, antithyroid and antiglication (Gökbulut et al., 2010; Peng et al., 2008; Zielińska and Zieliński, 2011). Therefore, it is very noteworthy to investigate the plants used in the treatment of diseases. The most plants are also waiting to be investigated scientifically (Karaoğul et al., 2011).The phenolic components of the $V$. agnus-castus plant, which is one of the most commonly applied natural phytochemicals today, were determined in this research.

\section{MATERIALS and METHODS}

\section{Plant material}

The material of the study consisted of Vitex agnus-castus (L.) that grow naturally in Muğla-Ula region Karabörtlen area $(81 \mathrm{~m})$, May-2019 . V. agnus-castus leaf and flowers were collected from Karabörtlen area $(81 \mathrm{~m})$, The leaves shoots and flowers of each plant were collected to be used in extraction system. The collected plants were put in plastic bags, and each bag was labeled. The data related to the collection time, place, and elevation were written on the label of each bag. These plants were then dried in a semi-shadowy and airy place at room temperature (at $25^{\circ} \mathrm{C}$ ) to be used in extraction system. These plants samples were identified and kept at Muğla Sıtkı Koçman University Research Center Laboratory

\section{Standards and reagents}

The HPLC grade solvents such as methanol, acetonitrile, and hexane are used for extraction of phenolic compounds and were purchased from Merck (Darmstadt, Germany). Pyrogallol, homogentisic acid, 3,4-dihydroxybenzoic acid, gentisic acid, pyrocatechol, galantamine, 4-hydroxy benzoic acid, 3,4dihydroxybenzaldehyde, catechin hydrate, vanillic acid, caffeic acid, syringic acid, vanillin, epicatechin, catechin gallate, p-coumaric acid, ferulic acid, rutin, trans 2hydroxy cinnamic acid, myricetin, resveratrol, transcinnamic acid, luteolin, quercetin, naringenin, genistein, apigenin, kaempferol, hesperetin, chlorogenic acid and chrysin were used as the standards of phenolic compounds and purchased from Sigma-Aldrich Chemie $\mathrm{GmbH}$ (Steinheim, Germany). HPLC grade ultra-pure water was $18.2 \mathrm{M} \Omega$.

\section{Ultrasonic-assisted extraction of phenolic compounds from plant samples}

Kıvrak et al., (2018) described the liquid-liquid extraction procedure by ultrasonic assisted extraction of phenolic components of $V$. agnus-castus samples which was performed with minor modifications. Approxiametly, $2.0 \mathrm{~g}$ of Vitex agnus-castus samples weighed into a centrifuge tube, and $15 \mathrm{~mL}$ of hexane and $30 \mathrm{~mL}$ of acetonitrile were added to extract the plant. The extract is mixed for 2 min then, extracted in an ultrasonic bath for $10 \mathrm{~min}$ followed by centrifuge at $1792 \mathrm{~g}$.Then, the acetonitrile layer was separated. Those steps were applied two times more. The acetonitrile extracts were combined and washed with petroleum ether, and then evaporated to dryness using nitrogen evaporator. The residue was dissolved in water:methanol mixture (60:40, $\mathrm{v} / \mathrm{v})$, and then filtered through $0.20 \mu \mathrm{m}$ PTFE syringe filter and $2 \mu \mathrm{L}$ injected to UPLC-ESI-MS/MS (Waters Acquity Ultra Performance LC, Xevo TQ-S MS-MS) instrument, which stated in a previous method with slight modification(Kıvrak et al., 2018).

\section{UPLC-MS/MS analysis of individual phenolic compounds}

The phenolic profiles of the $V$. agnus-castus samples were determined according to the procedure given in (Kıvrak et al., 2018). Analysis of phenolic compounds from $V$. agnus-castus was carried out using an UPLC - ESI - MS / MS instrument. Mass spectrometry parameters, verification and quantization mass shift $\left(\mathrm{m} \mathrm{z}^{-}\right)$and their collision energies have been described in previous literature (Kivrak et al., 2018).

Phenolic compounds were analyzed with using a C18 column (Acquity UPLC BEH C18 $100 \mathrm{~mm} \times 2.1 \mathrm{~mm}$, 1.7$\mu \mathrm{m}$ particle size). Compounds were separated by gradient elution. The mobile phases consisted of $0.5 \%$ acetic acid in water (S1) and $0.5 \%$ acetic acid in acetonitrile (S2). Elution was carried out with eluent (S1) and eluent (S2) at a flow rate of $0.650 \mathrm{~mL} \mathrm{~min}-1$ at $40^{\circ} \mathrm{C}$ column oven temperature. Elution sequence from 1 minute linear gradient mode at $99 \%$ (S1), from $99 \%$ to $70 \%$ (S1) over 10 minutes, from $70 \%$ to $99 \%$ (S1) in 2 minutes, and finally a (S1) 3 minute plateau at $99 \%$ of value. Re-equilibration of the column was achieved at the end plateau. Tandem mass spectrometer parameters were ion mode elektrospray ionization nebulizer 7.0 bar, source temperature $150^{\circ} \mathrm{C}$, desolvation temperature $500{ }^{\circ} \mathrm{C}$.

\section{RESULTS and DISCUSSION}

In this study, the phenolic composition obtained from $V$. 
agnus-castus was analyzed and determined by UPLC-ESIMS $\mathrm{MS}^{-}$method. In this study, phenolic composition of $V$. agnus-castus leaf and flower samples was examined and a total of 8 phenolic components were determined. Major components were; protocatechuic acid (4906.02 $\mathrm{mg} \mathrm{kg}{ }^{-}$); 4-hydroxy benzoic acid (1603.88 $\mathrm{mg} \mathrm{kg}^{-}$), gentisic acid ( $\left.668.49 \mathrm{mg} \mathrm{kg}^{-}\right)$. Other components that we determined at high rates which are caffeic acid (84.29 $\mathrm{mg} \mathrm{kg}^{-}$), vanilic acid (69.56 $\mathrm{mg} \mathrm{kg}^{-}$), 3-4-dihydroxy benzaldehyde ( $\left.58.63 \mathrm{mg} \mathrm{kg}^{-}\right)$. Additionally, ferulic acid and p-coumaric acid components were detected at low rates (Table 1). The major phenolic compounds of $V$. agnus-castus are found; protocatechuic acid (4906.02 $\mathrm{mg} \mathrm{kg}{ }^{-}$); 4-hydroxy benzoic acid (1603.88 mg $\mathrm{kg}^{-}$), gentisic acid (668.49 $\mathrm{mg} \mathrm{kg}^{-}$). Protocatechuic acid and 4hydroxy benzoic acid are deriveties of the phenolic acid and a large variety of edible plants and possesses various pharmacological activities are found. Protocatechuic acid and 4-hydroxy benzoic acid, are valuable compounds for the synthesis of several bioproducts with potential applications in food, cosmetics, pharmacy, fungicides, etc (Vang et al. (2018).

In the studies conducted in the literature, Demirtaş and Pişkin, (2020) investigated 4 phenolic components in the samples of $V$. agnus-castus $L$. fruit extract, and these components and their ratios were respectively; gallic acid (126.9 ( $\left.\mu \mathrm{g} \mathrm{g}^{-}\right)$; caffeic acid (63.3 ( $\left.\mu \mathrm{g} \mathrm{g}^{-}\right)$; luteolin (344.1 ( $\left.\mu \mathrm{g} \mathrm{g}^{-}\right)$; p-Coumaric acid (15.6 ( $\left.\mu \mathrm{g} \mathrm{g}^{-}\right)$. In a study conducted in Denizli, the phenolic component content of $V$. agnus-castus seed samples were inventigated as gallic acid $0.281\left(\mu \mathrm{g} \mathrm{g}^{-}\right), 4$-Hydroxy benzoic acid $21.506\left(\mu \mathrm{g} \mathrm{g}^{-}\right)$, caffeic acid $0.647\left(\mu \mathrm{g} \mathrm{g}^{-}\right)$and ferulic acid $0.122\left(\mu \mathrm{g} \mathrm{g}^{-}\right)$
(Parlak et al., 2016).

Phenolic extractives detected in branch and trunk samples of $V$. agnus-castus (Chaste) plant species are gallic acid $\left(0.02 \mathrm{mg} \mathrm{g}^{-}\right)$, protocathic acid $\left(0.06 \mathrm{mg} \mathrm{g}^{-}\right)$, phydroxybenzoic acid $\left(0.95 \mathrm{mg} \mathrm{g}^{-}\right)$, chlorogenic acid $(0.57$ $\left.\mathrm{mg} \mathrm{g}^{-}\right)$, epicatechin $\left(0.02\left(\mathrm{mg} \mathrm{g}^{-}\right)\right.$, syringic acid $(0.02 \mathrm{mg}$ $\left.\mathrm{g}^{-}\right)$, vanillin $\left(0.01 \mathrm{mg} \mathrm{g}^{-}\right), \mathrm{p}$-coumaric acid $\left(0.04 \mathrm{mg} \mathrm{g}^{-}\right)$, benzoic acid $\left(0.21 \mathrm{mg} \mathrm{g}^{-}\right)$, cinnamic acid $\left(0.01 \mathrm{mg} \mathrm{g}^{-}\right)$, quercetin $\left(0.02 \mathrm{mg} \mathrm{g}^{-}\right)$, luteolin $\left(0.04 \mathrm{mg} \mathrm{g}^{-}\right)$and campherol (0.10 $\mathrm{mg} \mathrm{g}^{-}$) (Ceviz, 2016).

In another study, they determined the amount of caffeic acid and chlorogenic acid in $V$. agnus-castus leaf and fruit samples obtained from Marmaris, Antalya and Isparta regions. They determined the highest rate of caffeic acid

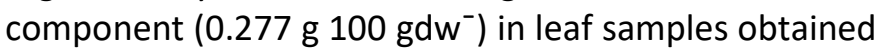
from Marmaris region and the highest rate of chlorogenic acid component in fruit samples obtained

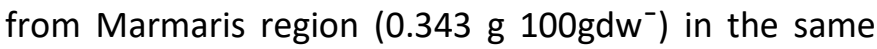
study (Şarer and Gökbulut, 2008). Caffeic acid component one of the phenolic components we determined in the $V$. agnus-castus leaf and flower samples analyzed in this research lower than rate compared to (Parlak et al., 2016), (Demirtaş and Pişkin, 2020) and Şarer ve Gökbulut (2008) researchs.The ratio of p-coumaric acid component determined in the $V$. agnus-castus fruit extract in the study of Demirtaş and Pişkin (2020) is consistent with this study. The protocathic component of $V$. agnus-castus (Hayit) in research of Ceviz (2016) was determined at a higher rate in this study and the p-coumaric acid component was found at lower rates in this study.

Table 1. Phenolic compounds of Vitex agnus-castus extracts $\left(\mathrm{mg} \mathrm{kg}^{-1}\right)$ and method parameters for the phenolic compounds analysis using UPLC-ESI-MS/MS

\begin{tabular}{|c|c|c|c|c|c|}
\hline Compounds & $\begin{array}{l}\text { Vitex agnus-castus } \\
\left(\mathrm{mg} \mathrm{kg}^{-}\right)\end{array}$ & Quantification>confirmatory transition $(\mathrm{m} / \mathrm{z})$ & ${ }^{\mathrm{a} C o n e}(\mathrm{~V})$ & ${ }^{\mathrm{b}} \mathrm{CE}(\mathrm{V})$ & ${ }^{\mathrm{C}} \mathrm{RT}$ (Min) \\
\hline 4-Hydroxy benzoic acid & $1603.88 \pm 0.09$ & $136.98>93.03,65.10$ & 10 & 25,14 & 2.75 \\
\hline 3-4-Dihydroxy benzaldehyde & $58.63 \pm 0.02$ & $137.00>91.93,107.94,136.00$ & 8 & $21,20,18$ & 2.76 \\
\hline Trans-cinnamic acid & ND & & & & \\
\hline Vanillin & ND & & & & \\
\hline Gentisic acid & $668.49 \pm 0.05$ & $153.05>109.04,108.03,81.00$ & 10 & $20,20,12$ & 1.85 \\
\hline Protocatechuic acid & $4906.02 \pm 0.08$ & $153.06>108.00,81.01,91.01$ & 10 & $20,25,20$ & 1.85 \\
\hline p-Coumaric acid & $11.35 \pm 0.04$ & $163.01>119.04,93.00,117.01$ & 5 & $27,27,15$ & 4.65 \\
\hline Vanilic acid & $69.56 \pm 0.03$ & $166.98>151.97,108.03,123.03$ & 20 & $18,12,14$ & 3.61 \\
\hline Caffeic acid & $84.29 \pm 0.07$ & $179.10>135.14,107.10,133.9$ & 32 & $23,23,24$ & 3.65 \\
\hline Ferulic acid & $8.97 \pm 0.01$ & $193.03>134.06,178.00,149.02$ & 20 & $16,12,13$ & 5.36 \\
\hline Kaempferol & ND & & & & \\
\hline Myricetin & ND & $136.98>93.03,65.10$ & & & \\
\hline
\end{tabular}

(m/z) : Quantification>confirmatory transition, ND: not determined.

${ }^{a}$ Cone : Cone Voltage ${ }^{b} \mathrm{CE}$ : Collision Energy ${ }^{\mathrm{c}} \mathrm{RT}$ : Retention time. 
There are more than 8000 known types of phenolic compounds (Cartea et al., 2011). Vitex extracts showed an important diversity and variability between plant parts (Berrani et al., 2021). A lot of work have been carried out using various techniques until today in order to determine phenolic composition of $\mathrm{V}$. agnus castus. Kawashty et al. (2016) identified 13 phenolic acid components in V. trifolia L. samples. These components

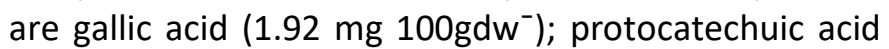

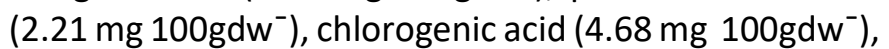

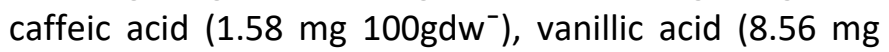

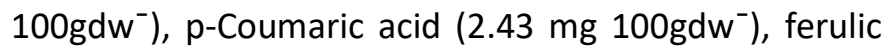
acid $\left(6.00 \mathrm{mg} 100 \mathrm{gdw}^{-}\right)$, Iso-ferulic acid $(2.12 \mathrm{mg}$ $\left.100 \mathrm{gdw}^{-}\right)$, ellagic acid $\left(9.29 \mathrm{mg} 100 \mathrm{gdw}^{-}\right)$, salicylic acid

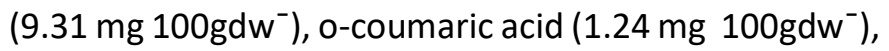

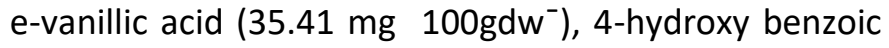
acid ( $16.38 \mathrm{mg} 100 \mathrm{gdw}^{-}$). Protocatechuic acid, caffeic acid, vanillic acid, ferulic acid component ratios found out in this study were lower than those determined by Kawashty et al. (2016) in V. trifolia L. samples.

The content of phenolic compounds levels depend on several factors such as, growing conditions, geographical origin, processing and storage conditions, genetic factors, ripening process, as well as stress conditions such as UV radiation, wounding air pollution and exposure to extreme temperatures (Yamasaki et al., 1995; Figueiredo et al., 2008).

In the present work, the phenolic composition of $V$. agnus-castus were identified using UPLC-ESI-MS/MS instrument. The lack of information about phenolic composition of $V$. agnus-castus using UPLC-ESI-MS/MS makes this study important. In the light of results, there is some differences fenolic composition and rates among the litaratüre and our results. This indicates that the analysis methods used to determine of the $V$. agnuscastus leaves and flowers samples phenolic components can affect the phenolic component profile and rates also. In conclusions, nowadays wild plants are applied more intensely in more areas than in previous years. It is a great importance to determine some biochemical contents of medicinal and aromatic plants, such as antioxidants and phenolic substances. In terms of health, interest in phenolic compounds with natural antioxidant properties is growing every day due to the toxic and carcinogenic effects of synthetic antioxidants. Phenolic compounds as antioxidants can prevent many diseases such as cancer, heart disease, cataracts, eye diseases, old age diseases, etc. According to this research on Vitex agnus-castus leaf and flower samples, $V$. agnus-castus is rich in phenolic components and was determined by analysis. This research can be used to guide current and future research.

\section{ÖZET}

Amaç: Bu çalışmada ülkemizin önemli tıbbi bitkilerinden olan Verbenaceae familyasına ait, Vitex agnus-castus L. (Hayıt)'ın fenolik bileşenlerinin belirlenmesi amaçlanmıştır.

Yöntem ve Bulgular: Bu çalışmada, Karabörtlen (81m) ekolojik koşullarda çiçeklenme döneminde Vitex agnuscastus $\mathrm{L}$. yaprak ve çiçek örnekleri toplanmıştır. Örnekler daha sonra ekstraksiyon işleminde kullanılmak üzere oda sıcaklığında $\left(25^{\circ} \mathrm{C}\right.$ 'de) yarı gölgeli ve havadar bir yerde kurutulmuştur. Çalışmamızda Vitex agnus-castus'ten elde edilen fenolik bileşiklerin kompozisyonu UPLC-ESIMS/MS yöntemiyle analiz edilip tespit edilmiştir. Çiçeklenme döneminde elde edilen yaprak ve çiçek örneklerinde toplamda 8 fenolik bileşen belirlenmiştir. Hayıtın (Vitex agnus castus L.) çiçeklenme döneminde yaprak ve çiçek örneklerinden elde edilen fenolik bileşenleri arasında en etkili bileşenler; protokatekuik asit $4906.02\left(\mathrm{mg} \mathrm{kg}^{-}\right)$; 4-hidroksi benzoik asit $1603.88 \mathrm{mg}$ $\left.\mathrm{kg}^{-}\right)$, gentisik asit $668.49\left(\mathrm{mg} \mathrm{kg}^{-}\right)$olarak tespit edilmiştir. Genel Yorum: Bitki kaynaklı doğal ürünler ve bitkisel ürünlerin içeriğinde bulunan birçok bileşen çeşitli farmakolojik özelliklerinden dolayı son yıllarda büyük ilgi görmüştür. Bitkilerde bulunan bu biyoaktif bileşiklerin çoğu, terpenoidler, alkaloidler ve fenolik bileşenler gibi ikincil (sekonder) metabolitleridir. Antioksidan olarak fenolik bileşikler kanser, kalp hastalığı, katarakt, göz hastalıkları, yaşlıık hastalıkları vb. birçok hastalığı önleyebilmektedir. Bu çalışmanın sonuçları Vitex agnuscastus yaprak ve çiçek örneklerinin fenolik bileşenler bakımından zengin olduğunu göstermiştir.

Çalışmanın Önemi ve Etkisi: Bu çalışmanın sonuçları, $V$. agnus-castus'un potansiyel bir fenol kaynağına sahip olduğuna ve gıda, ilaç ve kozmetik endüstrilerinde fenolik bileşenler açısından oksidatif hasarı azaltmak için koruyucu bir ajan olarak kullanılabileceğini gösterdi. Bu çalışma mevcut ve gelecekteki araştırmalar için rehberlik etmek için kullanılabilir.

Anahtar Kelimeler: Verbenaceae, Vitex agnus castus, fenolik bileşen, Muğla-Ula, Türkiye.

\section{CONFLICT OF INTEREST}

The authors declare no conflict of interest for this study.

\section{REFERENCES}

Arokiyaraj S, Perinbam K, Agastian P, Kumar RM (2009) Phytochemical analysis and antibacterial activity of Vitex agnus-castus. International Journal of Green Pharmacy. 3(2): 162-164. 
. Asdadi A, Hamdouch A, Oukacha A, Moutaj R, Gharby, $S$, Harhar H, El Hadek M, Chebli B, Idrissi Hassani LM (2015) Study on chemical analysis, antioxidant and in vitro antifungal activities of essential oil from wild Vitex agnus-castus L. seeds growing in area of Argan Tree of Morocco against clinical strains of Candida responsible for nosocomial infections. Journal de Mycologie Médicale 25(4): 118-127.

Bachrach ZY (2012) Contribution of selected medicinal plants for cancer prevention and therapy. Acta Facultatis Medicae Naissensis 29(3): 117-123.

Balasundram N, Sundram K, Saman S (2006) Phenolic compounds in plants agri-industrial by-products: Antioxidant activity, occurence, and potential uses. Food Chemistry 99(1): 191-203.

Baydar H (2005) Medical, aromatic and arbitrary plants science and technology (in Turkish). Faculty of Agriculture, University of Suleyman Demirel, no:51, Isparta. pp 216.

Baytop T (1999) Treatment with palnts in Turkey. Nobel Medical Publishing, No:2, i̇stanbul. pp 480.

Bohnert KJ, Hahn G (1990) Phytotherapie in Gynäkologie und Geburtshilfe: Vitex agnus-castus (Keuschlamm). Erfahrungsheilkunde 39: 494-502.

Berrani A. Marmouzi I, Bouyahya A, Kharbach $M$, Hamdani ME, Jemli ME, Lrhorfi A, Zouarhi M., Faouzi MEA, Bengueddour R (2021) Phenolic compound analysis and pharmacological screening of Vitex agnus-castus. Functional Parts BioMed Research International 10.

Brickell C, Zuk JD (1996) A-Z Encyclopedia of Garden Plants. DK Publishing Inc., New York. USA. pp 1095.

Cabral C, Gonçalves MJ, Cavaleiro C, Salgueiro L, Antunes T, Sevinate-Pinto I, Sales F. (2008) Vitex ferruginea schumach. Et. Thonn. subsp. amboniensis (Gürke) Verdc.: glandular trichomes micromorphology, composition and antifungal activity of the essential oils. Journal of Essential Oil Research 20(1): 86-90.

Cartea, M.E., Francisco, M., Soengas, P. and Velasco, P. (2011) Phenolic compounds in Brassica vegetables. Molecules 16(1): 251-280.

Ceviz AU (2016) Investigation of chemical composition and phenolic extractives of Laurus nobilis, Tamarix parviflora and Vitex agnus-castus species. M.Sc. Thesis, Suleyman Demırel University, Graduate School of Natural and Applied Sciences, Dept. of Forest Product Engineering, 69p.

Cheifetz A, Double C, Barnard L, Imwold D (1999) Trees and shrubs. Laurel Glen Publishing, San Diego. USA. pp 1008.

Çenet M, Toroğlu S (2006) The methods used to determine antimicrobial activity of the plants and their application area. Kahramanmaras Sutcu Imam University Journal of Engineering Sciences 9(2): 1220.

Demirtaş A, Pişkin i (2020) Effects of Urtica dioica, Matricaria chamomilla, and Vitex agnus-castus extracts on in vitro rumen fermentation under normal and acidosis conditions. Ankara University journal of Faculty of Veterinary Medicine 67: 15-22.

Fakir H, Erbaş S, Özen M, Dönmez IE (2014) The effects of different harvest dates on essential oil content and composition in chaste tree (Vitex agnus-castus L.). European Journal of Science and Technology 1(2): 2528.

Figueiredo AC, Barroso JG, Pedro LG and Scheffer JJ (2008) Factors affecting secondary metabolite production in plants: volatile components and essential oils. Flavour and Fragrance J. 23(4): 213226.

Gökbulut A, Özhan O, Karacaoğlu M, Şarer E (2010) Radical scavenging activity and vitexin content of Vitex agnus-castus leaves and fruits. Fabad J. Pharm. Sci. 35: 85-91.

Gülsoy G (2011) Evaluation of Vitex agnus-castus fruits in terms of phytotherapy. M.Sc. Thesis, İstanbul University, Institute of Health Science, Dept. of Pharmacognosy, 41p.

Hajdú Z, Hohmann JP Forgo, Martinek T, Dervarics M, Zupkó I, Falkay G, Cossuta D, Máthé I (2007) Diterpenoids and favonoids from the fruits of Vitex agnus-castus and antioxidant activity of the fruit extracts and their constituents. Phytotherapy Research. 21(4): 391-394.

Harvey AL (2008) Natural products in drug discovery. Drug Discov Today 13: 894-901.

Ignjatović Đ, Tovovılovıć G, Šošić-Jurjević B, Filipović B, Janać B, Milošević V, Tomić M (2012) Bioactivity of the essential oil from berries of Vitex agnus-castus in middle aged male rats. Digest Journal of Nanomaterials and Biostructures 7(4): 1727-1734.

John JE. (2009) Natural products-based drug discovery: Some bottlenecks and considerations. Curr. Sci. 96: 753-54.

Jose J, Raju D, Nayak P (2018) Microspheres-novel drug delivery carrier for plant extracts for antibacterial activity. Research J. Pharm. and Tech. 11: 1681-1684.

Kähkönen MP, Hopia Al, Vuorela HJ, Rauha JP, Pihlaja K, Kujala TS, Heinonen M (1999) Antioxidant activity of planat extracts containing phenolic compounds. J. Agric. Food Chem. 47: 3954-3962.

Karaoğul E, Ertaş M, Altuntaş E and Alma MH (2011) The chemical composition of laurel (Laurus nobilis) grow in the Black Sea and Mediterranean regions, KSU J. of 
Engineering Sci. Special issue: 74-77.

Kawashty S A, Soliman HM, Boquellah NA (2016) Chemical and biological characterize of some species from Mahdadh Dhahab region. J. İnnov. Appl. Pharm. Sci. 1(3): 62-70.

Kayacık H (1966) Special systematic of forest and park trees, III. volume Angiospermae (Angiospermae) (in Turkish). Istanbul University Faculty of Forestry Publications, Kutulmuş Printing House, No:106, Istanbul, pp 291.

Kıvrak Ş, Kıvrak I, Karababa E (2018) Analytical evaluation of phenolic compounds and minerals of Opuntia robusta J.C. Wendl. and Opuntia ficus-barbarica A. Berger. International J. of Food Properties 21(1): 244256.

Kulkarni SG, Vijayanand P (2010) Effect of extraction conditions on the quality characteristics of pectin from passion fruit peel (Passiflora edulis f. flavicarpa L.). Food Science and Technology 43: 1026-1031.

Kültür Ş (2007) Medicinal plants used in Kırklareli Province. Journal of Ethnopharmacol. 111(2): 341364.

Latovi M, Aliakbarian B, Casazza AA, Seffen M, Converti A, Perego P (2012) Extraction of phenolic compounds from Vitex agnus-castus L. Food and Bioproducts Processing 90: 748-754.

Maksimović ZA, Đorđević S, Mraović M (2005) Antimicrobial activity of Chenopodium botrys essential oil. Fitoterapia 76: 112-114.

Meral R, Doğan is, Kanberoğlu GS (2012) Fonksiyonel gıda bileşeni olarak antioksidanlar. Iğdır University Journal of the Institute of Science and Technology 2(2): 45-50.

Mohammed FS, Karakaş M, Akgül H, Sevindik M (2019) Medicinal properties of Allium calocephalum collected from Gara mountain (Iraq). Fresen. Environ. Bull. 28(10): 7419-7426.

Njume C, Afolayan A, Ndip RN (2009) An overview of antimicrobial resistance and the future of medicinal plants in the treatment of Helicobacter pylori Infections. African Journal of Pharmacy and Pharmacology 3: 685-699.

Odenthal KP (1998) Vitex agnus castus L., traditional drug and actual indications. Phytotherapy Research 12: 160-161.

Ohyama K, Akaike T, Hirobe C, Yamakawa T (2003) Cytotoxicity and apoptotic inducibility of Vitex agnuscastus fruit extract in cultured human normal and cancer cells and effect on growth. Biological and Pharmaceutical Bulletin 26(1): 10-18.

Ono M, Eguchi K, Konoshita M, Furusawa C, Sakamoto J, Yasuda S, Ikeda T, Okawa M, Kinjo J, Yoshimitsu H,
Nohara T (2011) A new diterpenoid glucoside and two new diterpenoids from the fruit of Vitex agnuscastus. Chem. Pharm. Bull. (Tokyo). 59(3): 392-396.

Parlak B, Kara Y, Kılıç K (2016) Determination of phenolic compounds of chaste berry seeds (Vitex agnus-castus L.) grown in Denizli (Karahayit). Symposium on Euroasian Biyodiversity, May. 23-27, Antalya, Turkey. pp 151-152.

Peng $X$, Zheng $Z$, Cheng KW, Shan F, Ren GX, Chen F, Wang $M$ (2008) Inhibitory effect of mung bean extract and its constituents vitexin and isovitexin on the formation of advanced glycation endproducts. Food Chemistry 106(2): 475-481.

Phillipson D.J. (2001) Phytochemistry and medicinal plants. Phytochemistry 56(3): 237-243.

Proestos C, Sereli D, Komaitis M (2006) Determination of phenolic compounds in aromatic plants by RP-HPLC and GC-MS. Food Chemistry 95(1): 44-52.

Rahmatullah M, Jahan R, Safiul Azam FM, Hossan S, Mollik MAH, Rahman Taufiq (2011) Folk medicinal uses of Verbenaceae family plants in Bangladesh. Afr. J. Tradit. Complement Altern. Med. 8(5): 53-65.

Rani A, Sharma A (2013) The genus Vitex: a review. Pharmacognosy Reviews 7(14): 188-198.

Rishton GM (2008) Natural products as a robust source of new drugs and drug leads: Past successes and present day issues. American Journal of Cardiology 101: 43-49.

Sağlam H, Pabuçcuoğlu A, Kıvçak B (2007) Antioxidant activity of Vitex agnus-castus L. extracts. Phyther. Res. 21: 1059-1060.

Sevindik M (2018) Pharmacological properties of Mentha species. J. Tradit. Med. Clin. Natur. 7: 259263.

Sezik E, Özkök G, Sezik M (2013) A retrospective study on Vitex agnus castus L. preperation. SDU Medical Faculty Journal. 20(2): 48-53.

Stojković $D$, Soković $M$, Glamočlija J, Džamić A, Ćirić $A$, Ristić $M$, Grubišić $D$ (2011) Chemical composition and antimicrobial activity of Vitex agnus-castus L. fruits and leaves essential oils. Food Chemistry 128(4): 1017-1022.

Şarer E, Gökbulut A (2008) Determinatıon of caffeic and chlorogenic acids in the leaves and fruits of Vitex agnus-castus. Turkish Journal of Pharmacy 5(3): 167174.

Vang S, Bilal M, Hu H, Wang W, Zhang X (2018) 4Hydroxybenzoic acid-a versatile platform intermediatefor value-added compounds. Applied Microbiology and Biotechnology 102: 3561-3571.

Visioli F, Galli C, Plasmati E, Viappiani S, Hernandez A, Colombo C, Sala A (2000) Olive phenol hydroxytyrosol 
prevents passive smoking-induced oxidative stress. Circulation 102: 2169-2171.

Webster DE, LuJ, Chen SN, Farnsworth NR, Wang ZJ (2006) Activation of the mu-opiate receptor by Vitex agnus-castus methanol extracts: implication for its use in PMS. Journal of Ethnopharmacology 106(2): 216-221.

Willför SM, Hemming J, Reunanen M, Holmbom B (2003) Phenolic and lipophilic extractives in scots pine knots and stemwood. Holzforschung 57(4): 359-372.

Wuttke W, Jarry H, Christoffel V, Spengler B, SeidlováWuttke D (2003) Chaste tree (Vitex agnus-castus) pharmacology and clinical indications. Phytomedicine 10: 348-357.
Yamasaki H, R Heshiki, Ikehara N (1995) Leaf-goldenning induced by high light in Ficus microcarpa L-F, a tropical fig. Journal of Plant Research 108: 171-180.

Yiğit N, Benli M (2005) Ülkemizde yaygın kullanımı olan kekik (Thymus vulgaris) bitkisinin antimikrobiyal aktivitesi. Orlab On-Line Mikrobiyoloji Dergisi 3(8): 18.

Zielińska D and Zieliński H (2011) Antioxidant activity of flavone C-glucosides determined by updated analytical strategies. Food Chemistry 124: 672-678. 